\title{
RESEARCH PAPER \\ SANATIVE MEASURES AGAINST OFFENSIVE ODOUR THAT AFFECT INDIGENOUS TANNED LEATHERS IN GHANA
}

\author{
J. O. B. Boahin, K. Asubonteng, and V. E. Adu-Gyamfi \\ Department of Integrated Rural Art and Industry, College of Art and Social Sciences,
} KNUST, Ghana

\begin{abstract}
The negative impact of offensive odour associated with indigenous tanned leathers in Ghana is very high, thus making the promotion of the local leather products difficult in both local and external markets. This paper describes technology that can be adopted to control the offensive odour that affects the value of indigenous leather and leather products. Experiments were thus carried out using material and technical means to determine the possibility of curbing the offensive odour associated with these indigenous tanned leathers. The material and technical means refer to the use of sanding tool to sand off excess flesh from the fleshy side of leather; and soaking of leather in a soapy water made with perfume toilet-soap after which drying is done under room temperature. The experiments proved that the presence of excess flesh and fatty substances left after tanning and the use of untreated organic substances are the primary causes of offensive odour in the indigenous tanned leathers and leather products. The technology so devised has led to the production of leathers that are free of offensive odour.
\end{abstract}

Keywords: Odour, Flesh, Leather, Pelt, Tanned Leather.

\section{INTRODUCTION}

Leather is one of the most useful and versatile materials used today to make just about anything. The material is used to make everything from shoes to briefcases, and even furniture. When properly taken care of, the understated sheen and handsome look of leather can last for a lifetime.

Odour has been described as the sensation that results when olfactory receptors in the nose are stimulated by particular chemicals in gaseous form. According to Wikipedia, the free ency- clopedia (2011), "an odour is caused by one or more volatilised chemical compounds, generally at a very low concentration, that humans or other animals perceive by the sense of olfaction. Odours are also called smells, which can refer to both pleasant and unpleasant odours". Odour is perceived by smell, one of the five special senses; the special organ of smell is the nose, which is equipped with olfactory nerve. ("Smell” 2007).

Odours are light, volatile (easy to evaporate) chemicals that float through the air into recep- 
tors in the nose. These receptors send messages to the brain for processing which results in the sensation of smell. It is thought that there are hundreds of different receptors within the nose, distinct to each human. Each receptor is coded by different DNA to detect different odours.

This is one of the reasons why different people will have different sensitivity and reactions to smell. Reactions to odours can be very subjective (EPA, 2000). A smell may be pleasant to one person and unpleasant to someone else, making objective assessment of odour difficult to achieve (Kalman et al, 2000). An important parameter for odour impact is the odour concentration. Odour reflects the human response to odorants in the air and the base for odour concentration is the human odour threshold; odour threshold refers to the lowest detectable concentration. An odour contains hundreds of different gases where each gas has its own human odour threshold (Opatz, et al, 2000). Women are said to have often shown more results than men in the studies regarding olfactory sensitivity (Evans \& Cohen, 1987).

Different terms are used to describe pleasant or unpleasant odour for different purposes; fragrance, scent and aroma are used primarily for food and cosmetic products, sometimes used to refer to perfumes. Unpleasant odour in contrast, is referred to as malodorous, stench, reek, and stink. When people perceive what they regard as unacceptable amounts or types of odour, odorous emissions can become an "odour problem". Simply an odour problem results from an odour that is unpleasant (EPA, 2000). The propensity for leather to emit offensive odour to cause conflict even in the home is high, particularly one's interest in a leather artifact may overshadow the odour it emits which simultaneously yield discomfort to a cohabitant (Anonim, 2001). Odours are not quantifiable but they give rise to complaints and negative reactions from neighbours.

Offensive odour has been associated with the indigenous vegetable tanned leathers and leather products in Ghana from time immemorial, and as a result, many connoisseurs of indigenous leather products have had diminished taste for their products. However there is no known recorded evidence to indicate concrete efforts to curb the problem locally. Indigenous tanners have made several futile appeals for technical support to curb this unpleasant situation which is affecting the industry by way of local and external trade.

Tourists and lovers of crafts have been complaining about the foul odour, the worse situation occurs when the indigenous leather products are left in enclosed humid places or rooms. To subdue the offensive odour many lovers of indigenous leather products have had to keep these items in the open air for long periods of time before using them. This is particular with items meant for interior decoration, such as floor mats, place mats and pouffes. According to the American Environmental Protection Agency, the strength and intensity of an odour depends heavily on the prevailing weather conditions and will vary with small changes in wind speed and direction. At night or during colder months, atmospheric mixing is reduced and air close to the earth is trapped by a layer of colder air. In these conditions odours travel further and do not readily disperse (EPA, 2000).

In the case of raw leather and leather products, much is required to make them comfortable to use; in pursuance of this, experiments were carried out.

\section{Primary cause of odour}

Leather is organic, implying that it was alive and was the skin of an animal. Anytime a hide is taken from an animal it starts to break down, hence the need to preserve it. However, the processes for such preservation or tanning among indigenous tanners leave much to be desired, as finished products almost always have the problem of offensive odour.

After critically examining some indigenous 
tanned leather products under a microscope, it was detected that there were thin films of flesh left on the grained side of the leather, and this generated the foul odour when kept in a damp room or in a humid environment. These begin to decay when they come into contact with moisture or when the percentage of humidity is high.

\section{Secondary cause of odour}

Natural leather is made from tanned animal hide and animal skin. Tanners and leathermakers use both natural and artificial chemicals to treat and colour raw hide and skins and turn them into durable materials for clothes, bound books, furniture, and other uses. Excess odour from tannins left after tanning is a major drawback on the value of indigenous tanned leather. Indeed all the dyes, treatments, leather bathes and chemicals that most leather goes through have their own smell. Because all these liquids soak into the hide, they leave their own smell, mixing in with the leather smell. So some leather may smell stronger than others, depending on how it was treated. Leather also breathes, and always is letting out a little bit of the animal hide smell.

The secondary cause is further confirmed by Carl Jones (2008) that new leather items treated with natural tanning and coloring chemicals like vegetable dye and animal oils have a distinctly musky odour. Leather items treated with artificial or metallic compounds have an odour that is quite similar to plastic.

The use of organic substances, such as food residue and vegetable based adhesives used by indigenous craftsmen in the production of leather goods also contribute to the offensive odour emanating from finished items.

Animals slaughtered for their pelts are not often bathed, and as a result their pelts give off offensive smell. Again, blood stains and dirt that affect the fur during tanning also contribute to the offensive odour that emanates from them after tanning. According to Akyuz (2011) leather is known for its particularly high gas emissions. These emissions can sometimes be high enough to cause nuisance and discomfort (EPA, 2000). Furthermore reactions to odours can be very subjective: a smell may be pleasant to one person and unpleasant to someone else, making objective assessment of odour difficult to achieve (EPA, 2000).

Experiments carried out proved that the presence of excess flesh and fatty substances left after tanning are the primary causes of offensive odour associated with the indigenous tanned leather and leather products. This has led to the development of appropriate technology and discovery of substances that are effective in solving the problem of offensive odour emitting from leather. A careful understanding of the nature of odour is essential for the craftsman to develop the mechanism for its control on indigenous vegetable tanned leather.

Revelation is made from research findings on the existence of seven primary odours as camphor like, musky, floral, peppermint like, ethereal (dry-cleaning fluid, for example), pungent (vinegar like), and putrid-corresponding to the seven types of smell receptors in the olfactory-cell hairs. The odour from leather is classified under putrid due to the attending putrefaction.

In the western world there have been several efforts to develop chemicals to remove odour from vegetable tanned leathers; among these are substances such as OdorXit, Baking soda, and Vinegar. Despite the use of these substances the odour easily resurfaces once leather comes into contact with moisture for a longer period of time and, this is largely due to the presence of the excess flesh that still remains on the flesh side of the leather even after tanning. Besides, local leather workers do not have access to these chemicals, and where they are accessible they are simply too expensive for their budget.

The introduction of leather soap or toilet soap 


\section{Boahin et al.}

in the research is meant to take advantage of its functional value. Soap has been defined as a cleansing agent or detergent made from animal and vegetable fats, oils and greases. Chemically, the sodium or potassium salt is a fatty acid, formed by the interaction of fats and oils with alkali (Soap, 2007).

Most soaps remove grease and other dirt because some of their components are surfaceactive agents, or surfactants. Surfactants have a molecular structure that acts as a link between water and the dirt particles, loosening the particles from the underlying fibers or outer surfaces to be cleaned. The character of toilet soap makes it the most appropriate to be used.

Collins English Dictionary (2003), defines toilet soap as a mild soap, often coloured and scented used for washing oneself.

\section{MATERIALS AND METHODS:}

Vegetable tanned leathers found at different indigenous tanneries in Ghana are produced through the same tanning procedures. This is largely due to the fact that most of the tanners are migrants from northern part of Ghana, particularly Tamale the capital of Northern Region of Ghana and they use virtually the same type of tannins. As stated earlier the following experiments were meant to explore means of solving the problem of offensive odour that is associated with Ghanaian indigenous tanned leathers. To ascertain the viability of the selected techniques of the research to curb offensive odour on leathers in Ghana, leathers from two different indigenous tanneries were selected. These were leathers from Hausa Zongo in Tamale and Asawase in Kumasi.

\section{Experiment 1:}

Two sheets of indigenous tanned leathers were taken through post tanning processes whereby the fleshy sides of these indigenous tanned leathers were sanded by using 60 grit sanding paper that is wrapped around a piece of wooden block. The leathers were then soaked in water to soften them and later washed to get rid of the excess flesh and tannins left after tanning. The washed tanned leathers were stretched taut with the aid of thumb pins and allowed to dry in a shade. Sun dried leathers yield bony leathers which are difficult to work with. When dried a smooth round bottle was used to burnish the grainy sides of the leathers after which a 60 grit abrasive paper was used to create a fluffy effect on their fleshy sides.

Finally the treated leathers together with two untreated ones were left hanging in a cool humid room for thirty days; this was meant to observe the effect of such humidity on them.

\section{Experiment 2:}

Two sets of indigenous tanned leathers were sanded to remove the excess flesh and fatty substances left after tanning. They were afterwards soaked in clean water that had been made soapy with 'Lux' (a toilet soap) for 30 minutes. Afterwards, they were tautly stretched over stretcher boards and wiped dry with a clean cloth to accelerate drying. Drying was done under room temperature.

This secondary treated leathers were kept in a damp humid room for thirty days to observe the effect such condition will have on them as done with experiment (1) one.

\section{Experiment 3:}

\section{Controlling offensive odour in indigenous} tanned fur

The indigenous tanned fur was sanded on the fleshy side with sand paper to remove the excess flesh and fatty substances left after tanning. They were then soaked in clean water for one hour and then washed thoroughly on the fur side with 'Lux toilet soap'.

The leather was pulled taut and held firmly with three inch nails on a stretcher board, and then allowed to dry partially under room temperature over night. The partially dry fur is put into the tumbling machine for thirty minutes before it was removed. It was then brushed and made ready for use, see plates 2 and 3. 


\section{RESULTS AND DISCUSSION}

\section{Experiment 1:}

The secondary treated indigenous tanned leathers which were kept in a damp room did not emit any offensive odour after the thirty days period. The offensive odour associated with indigenous tanned leathers from the two tanneries was completely subdued after they had been dried. This was as a result of the thorough activities of sanding, soaking and washing and stretching as in Plate 1. Sanding off the fleshy side helped remove the remaining fleshy and fatty substances left after tanning, and by so doing, putrefaction - the process of decay caused by bacteria or fungal action - could not take place to generate offensive odour. On the other hand the leathers that were not given secondary treatment continued to emit offensive odour. Drying the leather under shade, coupled with the vigorous activity of burnishing with the smooth bottle softened the compressed fibers into soft, glossy grained leather.

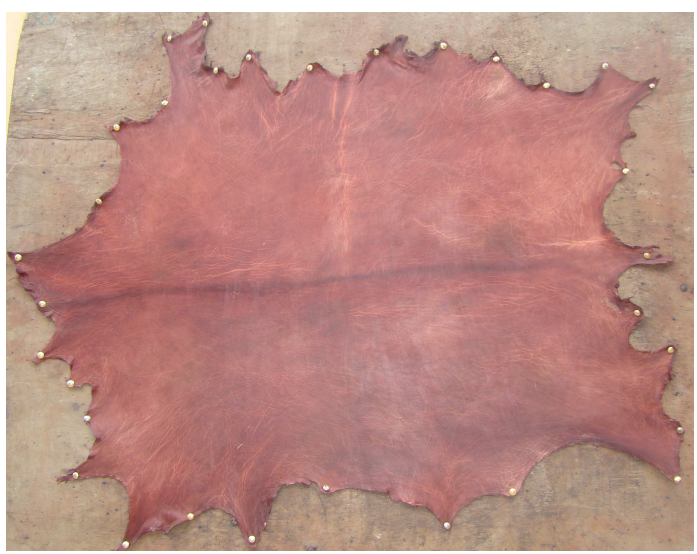

Plate 1: Leather on a Stretcher Board

\section{Experiment 2:}

The indigenous tanned leather was given a secondary treatment. Sanding removed the fatty substances and flesh left after tanning. These items usually absorb moisture thus allowing bacterial infection which causes decay on leather. Soaking and washing with soapy water with toilet soap, also made it possible for ex- cess tannins which also present offensive odour to be washed off and again made soft for easy stretching. Toilet soap is used as a detergent because of its low alkaline content. The indigenous tanned leathers treated in this manner did not emit offensive odour. This situation makes it possible for the leathers to be used soon after tanning without any problem of offensive ordour.

\section{Experiment 3:}

Controlling offensive odour in indigenous tanned fur.

The experiment resulted in the production of a finished fur that could be kept indoors without any offensive odour. Sanding off the flesh side of the fur removed the excess flesh left after tanning and as a result the presence of moisture could not cause any decay which is the primary cause of the unpleasant odour. Soaking and washing helped to remove dirt and blood stains that soaked the fur during slaughtering. These elements also contribute to the causes of offensive odour on indigenous tanned fur. After going through the selected processes, softly dried pelts were produced. Brushing helped the fur to align smoothly and made ready for use as in plates 2 and 3 .

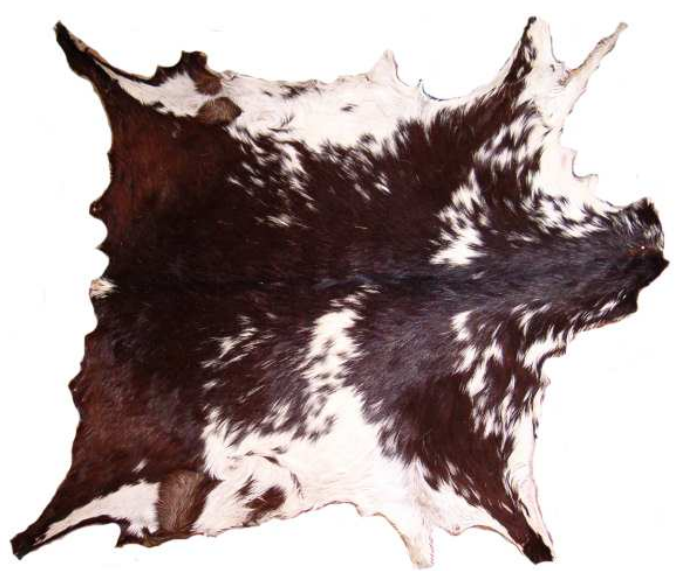

Plate 2: Fur of a Sheep

\section{CONCLUSION:}

Some techniques for controlling bad odour on 


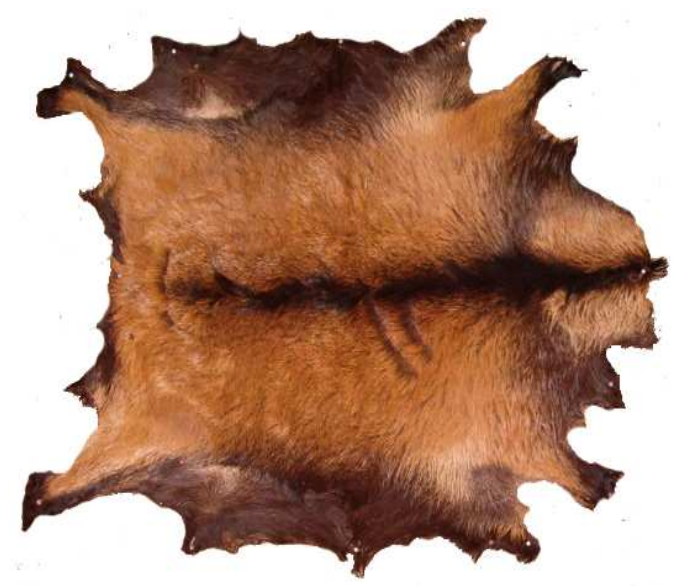

Plate 3: Fur of a goat

leather have been discovered through this research. These techniques were each tested and found useful, thus achieving the objective for the research.

It is recommended that people who rear animals or slaughter them always take into consideration the possibility of using the pelts of the animals as secondary materials for the production of leather and other related products. Proper care of the animals must be taken to protect their pelt.

It is further recommended that craftsmen who work with indigenous tanned leathers must painstakingly go through these processes to prepare the material before use. The secondary preparation of leather provides another line of production and employment avenues in the local leather industry.

\section{REFERENCES:}

Anonim (2001), European commission directorate-general JRC Joint Research Center Institute For Prospective Technological Studies (Servile) Technologies for Sustainable Development European IPPC Bureau Integrated Pollution Prevention and Control (IPPC), Reference-Document on Best Available Techniques for The Tanning of Hide And Skins. Retrieved From http:// eipppocb.jrc.es/ on 24/4/2011

Akyuz Fazli (2011) "Odour- An Important Problem In Leather Industry" Abant Izzet Universitesi, Gerede Meslek Yuksekokulu Deri Teknolojisi 14900 Gerede-Bolu, Turkiye. Akyuz fazli@ibu.edutr Retrieved on 27/7/2011 from http://www.chinaleather.org/ download/2-3/2-110.pdf.

Carl Jones, posted on May 22nd, 2008, "How to Get Rid of Leather Smell", Retrieved on $17 / 6 / 2011$, from ht t p:// www.howtogetridofstuff.com/odor-removal/ how-to-get-rid-of-leather-smell/

Collins English Dictionary - Complete and Unabridged (C)(2003), "Soap", HarperCollins Publishers Retrieved on 11/6/2011, from http://thefreeDictionary.com/_/miscCollins Products.asps?English

Evans, G.W. \& Cohen, S. (1987). Environmental strees, In: Stokols, D. and Altman, I. (eds): Handbook of Environmental Psychology. pp.571 - 610. John Wiley \& Sons Inc New York.

EPA, (2000), Guide to Field storage of Biosolids and other Organic By- Products used in Agriculture and for Soil Resource Management, US-EPA (Retrieved on 11/7/2011) from http://water.epa.gov/scitech/wastetech/ biosolids/guide.cfm.

Kalman, E. L., Lofvendsol. A., Winquist, F., and Luyndstrom . L., (2000). Classification of Complex Gas Mixtures from Autromotive Leather using an Electronic Nose, Analytica Chimica Acta, 403(pp. 31 - 38). Retrieved on 26/7/2011 from URL: http:// www.elsevier. Com/locate/aca

Opatz, O., Soiffer, A. \& Hummel, T., (2000), Are there Gender-Related Differences of Responses to Repetitive Intranasal Chemosensory Stimuli? In: Abstracts, Chemosensory responses in man, Erlangen Germany, 
Control of offensive odour in indigenous tanned Leathers ... 74

November 29 - December 3, 1999. Chemical Senses 25(6), p. 797.

'Smell'. (2007). Microsoft ${ }^{\circledR}$ Student 2008 [DVD]. Redmond, WA: Microsoft Corporation.
'Soap'. (2007). Microsoft® Student 2008 [DVD]. Redmond, WA: Microsoft Corporation.

Wikipedia, the free encyclopedia "Odour" (2011). Retrieved on 26/7/2011 from http://en.wikipedia.org/wiki/Odor 